\title{
EFFECT OF ANTINUTRITIONAL FACTORS AND EXTRUSION AT THE LEVEL OF CHOLESTEROL, TRIGLYCERIDES, TOTAL PROTEIN AND TESTOSTERONE IN SERUM OF BROILER CHICKENS
}

\author{
D. Beuković, D. Ljubojević, M. Beuković, D. Glamočić, S. Bjedov, V. \\ Stanaćev
}

Faculty of Agriculture, Trg Dositeja Obradovica 8, 21000, Novi Sad, Republic of Serbia Corresponding author: dejan.beukovic@stocarstvo.edu.rs

Original scientific paper

Abstract: The aim of this study was to evaluate the effects of various antinutritional factors and extrusion at the level of cholesterol, triglycerides, total protein and serum testosterone in broiler chickens. The experiment was set up as four treatments with four replications, where the chickens fed diets with different soybean varieties and different way of processing. The groups were: SS-raw standard strain, SL-raw soybeans with low levels of Kunitz trypsin inhibitor, SGstandard extruded soybeans and extruded soybeans LG with low levels of trypsin inhibitors. Significantly higher cholesterol levels compared to the SS group $(3,0125$ $\mathrm{mmol} / \mathrm{l})$ was in SL $(3,6125 \mathrm{mmol} / \mathrm{l})$ and SG $(3,8875 \mathrm{mmol} / \mathrm{l})$ group, while in relation to the LG $(3,4 \mathrm{mmol} / \mathrm{l})$ group was higher but the difference was not significant $(p>0.05)$. Triglyceride level was highest in the LG group $(1,6375$ $\mathrm{mmol} / \mathrm{l})$, followed by SL $(1,425 \mathrm{mmol} / \mathrm{l})$ and SG $(1,125 \mathrm{mmol} / \mathrm{l})$ groups and between these three groups no statistically significant differences. The lowest level of triglycerides in the SS group and is significantly lower than in the other three groups. Total protein level was highest in the SL group and significantly higher than the SG and LG groups $(\mathrm{p}<0.05)$ and highly significant difference compared to the SS group. Differences between groups SS, SG and SL are not statistically significant.The experiment confirmed that in addition to Kunitz trypsin inhibitors are heat labile and other factors that influence different biochemical parameters of blood.

Key words: soybean, cholesterol, triglycerides, testosterone, broilers

\section{Introduction}

Corn and soybeans are the main components in poultry nutrition. Soybean is one of the most common legumes in the world. Soybean is an excellent source of 
protein for poultry. Grain legumes contain thousands of different proteins (Pugalenthi et al., 2005). All legumes are a good source of lysine, but deficient in amino acids that contain sulfur. The high content of lysine in protein legumes is very important from the standpoint of a balanced diet and is probably more important than the total protein content, since it makes a significant addition of legume proteins in the diet with cereals, which are known for lysine deficiency (Sadeghi et al., 2009). Methionine is the first limiting amino acid for poultry in soybean seed and must be added to diets containing legumes (Carew and Gernat, 2006). Soy is also a rich source of carbohydrates, fiber, oligosaccharides, izoflavonida and minerals (Refstie et al., 1998). Soya bean contains $19.5 \%$ crude fat and relatively high content of lipids and carbohydrates, as well as the high protein content in grain is a rich source of energy (19.4 MJ / kg) (Siddhuraju et al., 2000). Value of legume protein is significantly reduced due to the presence of toxic proteins and other anti-nutritive factors (ANF), because they reduce the utilization of proteins from these grains, and limit the use of both soybeans and other legumes (Arija et al., 2006). The most important factors are anti nutritious inihibitor protease: a protein with specificity for trypsin, known as Kunitz trypsin inhibitor (Kunitz, 1945), and others capable of inhibiting trypsin and himotripsin, called Bowman-Birk trypsin inhibitor (Bowman, 1944; Birk, 1961; Yen et al., 1977). Trypsin inhibitor activity has a detrimental effect on the utilization of protein from legumes, especially cysteine, and he is already in deficit in grain (Kakade et al., 1969). Trypsin inhibitor also interferes with normal digestible protein in the intestinal tract through the inactivation of proteolytic enzymes secreted by the pancreas, and these enzymes also contain sulfur (Kakade et al., 1969). Other factors to take into account the hemagglutinin or lectins (Douglas et al., 1999), and goitrogens, antivitamins and indigestible oligosaccharides (Parsons et al., 2000). Inclusion of raw grain foods not only a negative effect on growth of chickens, but also leads to an increase in the relative weight of digestive organs, particularly the pancreas (Gertler et al., 1966; Arija et al., 2006, Brenes et al., 2008). Most of ANF are heat labile and destroyed by different thermal treatment processes nutrients, which include extrusion. Extrusion is defined as a process that is done under pressure, humidity and high temperatures. Effects of extrusion are quite prominent on the proteins, lipids and starch, by altering their physical, chemical and nutritional characteristics (El-Khalik and Janssens, 2010). Exposure to highnutrient components of temperature and pressure leads to a reduction in the number of microorganisms (Durmic et al., 2000), while destroying ANF. This technology has many advantages, including a wide possibility of application, low cost operations, high productivity, energy efficiency and high quality of the resulting product (Brenes et al., 2008). Adverse effects are loss of extruding thermo labile vitamins (vitamin A, E, thiamine), lipid oxidation (Lin et al., 1997), reduced availability of amino acids, especially lysine, which is associated with Maillard reaction (Moughan and Rutherfurd, 1996). 
Another way to improve the nutritional value of soybeans is to develop varieties with low levels of Kunitz inhibitor and / or lectins. New soybean varieties with low levels of anti-nutritive factors have been developed in recent decades. Hymowitz (1986) found soybean with low levels of Kunitz trypsin inhibitors. The name of this cultivar is a Kunitz and she is now a commercial variety. Better results are expected when genetically improved varieties subjected to thermal treatment (Palacios et al., 2004). Serbia has developed soybean varieties with low levels of Kunitz trypsin inhibitors under the commercial name "Soy Lana" and this variety was used in our expriment, while a varieties with a standard level of soybean KTI used in experiment was variety "Balkan". Total cholesterol and triglycerides are of particular importance for cardiovascular disease, especially coronary artery disease. It is known that soy proteins have a favorable effect on lowering cholesterol and triglycerides in the blood, but very little is known about the possible impact of trypsin inhibitors on these parameters.

The aim of our experiment was to determine the influence of extrusion and levels of Kunitz trypsin inhibitor on some blood biochemical parameters of broiler chickens.

\section{Materials and Methods}

A trial lasting 42 days was set up to investigate the effect of different levels of Kunitz trypsin inhibitor and extruded soybeans on blood parameters of broiler chickens. One-day old broiler chicks male hybrids Ross-308 were measured and arranged in 16 boxes, with each box were 60 chickens. The average initial weight of chicks was even and was $42.5+/-7 \mathrm{~g}$. The experiment included four groups with four replicates. The holding system has been the floor type, with a straw mat, and food and water were available ad libitum, with a light regime of 24 hours. Temperature and air circulation are controlled and regulated in accordance with the technology for hybrid Ross 308. Dead chickens are removed from buildings daily and mortality was below $3 \%$. The chickens were fed diets based on corn and soybeans. Starter mixture contained 23\% CP and $12.65 \mathrm{MJ}$ of metabolic energy and was used from 1st to 10th days. Starter mixture, where intake all chickens in the experiment and in it was included $51.77 \%$ corn, $24.46 \%$ full fat soybean meal, $15.34 \%$ soybean meal, $4 \%$ yeast, chalk, monocalcium phosphate, salt and premix. So this starter mixture was contained $23 \%$ crude protein and 12.60 MJ of metabolic energy. Experimental diet started from the tenth day, because strains with no or low levels of Kunitz trypsin inhibitors and lectins cant be successfully used in young chickhens without heat treatment (Palacios et al., 2004). Experimental mixtures were grower and finisher, and differed in four groups according to whether it was included raw or thermally processed soy standard varieties (Balkan) or varieties with low levels of Kunitz trypsin inhibitor 
(Lana). The mixtures used in the experiment were iso-energy and isoprotein. Chemical analysis of mixtures were made in Animal feed laboratory, Faculty of Agriculture in Novi Sad. Grower diets containing 22\% crude protein was used from 11 th to 24 th days, and finisher with $21 \%$ crude protein from 25 th to 42th days. Mixtures consisting of maize, soybean meal, dried yeast, chalk, monocalcium phosphate, salt and premix. The experimental mixture included 30\% soybean and to the treatments: 1) raw soybeans with low levels of Kunitz trypsin inhibitor (SL), 2) raw standard strain (SS), 3) extruded soybeans with low levels of Kunitz trypsin inhibitor (LG) and 4) standard extruded soybeans (SG). The levels of trypsin inhibitors in soybean are presented in Table 1.

Table 1. Level tripsin inhibitor in soybean

\begin{tabular}{|l|l|l|l|l|}
\hline $\begin{array}{l}\text { Group } \\
\text { Tretman }\end{array}$ & $\begin{array}{l}\text { SL } \\
\text { RKFSB }\end{array}$ & $\begin{array}{l}\text { SS } \\
\text { RCSB }\end{array}$ & $\begin{array}{l}\text { LG } \\
\text { EKFSB }\end{array}$ & $\begin{array}{l}\text { EG } \\
\text { ESBM }\end{array}$ \\
\hline TI $(\mathrm{mg} / \mathrm{g} / \mathrm{min})$ & 15.07 & $30.21^{\mathrm{A}}$ & 12.43 & 12.30 \\
\hline
\end{tabular}

A-values with superscript in same column are values with hi significant diference $(\mathrm{p}<0.001)$

With 28th days of age by two chickens from box ( 8 per treatment) were selected and placed in a metabolic cage. Their blood was taken 32 nd days from the wing vein, and before that were starved 12 hours. Blood seamples were left to stand for 2 hours at room temperature, then centrifuged at $3000 \mathrm{rpm}$ at $4^{\circ} \mathrm{C}$ for 15 minutes and then left in a freezer at $-18^{\circ} \mathrm{C}$ until analysis. Blood serum was analyzed on the automated analyzer COBAS MIRA Plus, Rosh manufacturers and used as commercial kits manufacturers Bio-Systems (Spain) for the determination of cholesterol (colesterol oxidase / peroxidase) and triglycerides (glycerol phosphate oxidase / peroxidase), Pointe SCENTIFIC inc. (USA) for determination of total protein (Biuret color reaction). Testosterone level was determined by immunofluorescence assay (Microplate immunoassay Chemilluminescence) per manufacturer's instructions (Monobind Inc., USA). The results were tested in STATISTICA 9 (Stat Soft), we used one way ANOVA test, and for the determination of significance was used LSD Fisher test. Differences were considered significant when $\mathrm{p}<0.05$, and together has significantly higher when $\mathrm{p}$ $<0.001$.

\section{Results}

Table 1 shows the levels of trypsin inhibitor content in soy and expect the highest level in the SS group and differed significantly $(p<0.001)$ than the other three groups. Slightly higher levels of trypsin inhibitors in the SL grain compared with the SG and LG, but the differences were not significant. Trypsin inhibitor values being higher in LG than in SG grain, which was not significant, but are 
expected to be reversed. Table 2 shows values obtained for cholesterol, triglycerides, total protein and serum testosterone in chickens. Cholesterol level was the highest in the SG group, and lowest in the group which was fed raw soybean and differences between these two treatments was statistically significant $(\mathrm{p}<0.05)$. Significantly higher cholesterol levels compared to the SS group and in the SL group, and higher in the LG group compared to the SS group, but the difference was not significant $(\mathrm{p}>0.05)$. Between SL, SG and LG groups no statistically significant differences in the level of cholesterol in serum. Triglyceride level was highest in the LG group, followed by SL and SG groups and between these three groups no statistically significant differences. The lowest level of triglycerides in the SS group and is significantly lower than in the other three groups. Total protein level was highest in the SL group and significantly higher than the SG and LG groups $(\mathrm{p}<0.05)$ and highly significant difference compared to the SS group.

Table 2. Biochemical blood parameters of broiler chickens

\begin{tabular}{|l|c|c|c|c|}
\hline \multicolumn{1}{|c|}{ Tretman } & SS & SL & SG & LG \\
\hline Cholesterol $(\mathrm{mmol} / \mathrm{l})$ & $3.0125^{\mathrm{b}}$ & $3.6125^{\mathrm{a}}$ & $3.8875^{\mathrm{a}}$ & $3.4^{\mathrm{ab}}$ \\
\hline Triglyceride $(\mathrm{mmol} / \mathrm{l})$ & $0.7125^{\mathrm{b}}$ & $1.425^{\mathrm{a}}$ & $1.125^{\mathrm{a}}$ & $1.6375^{\mathrm{a}}$ \\
\hline Total Protein $(\mathrm{g} / \mathrm{l})$ & $33.625^{\mathrm{Bc}}$ & $43.3^{\mathrm{Aa}}$ & $35.4375^{\mathrm{c}}$ & $36.75^{\mathrm{c}}$ \\
\hline Testosterone $(\mathrm{ng} / \mathrm{ml})$ & $0.270875^{\mathrm{b}}$ & $0.3155^{\mathrm{ab}}$ & $0.4935^{\mathrm{a}}$ & $0.3805^{\mathrm{ab}}$ \\
\hline
\end{tabular}

A, B-values with different values in superscript in the same row are statistically highly significantly different $(\mathrm{p}<0.001)$

$\mathrm{a}, \mathrm{b}, \mathrm{c}$-values with different values in superscript in the same row are significantly different $(\mathrm{p}<0.05)$

Differences between groups SS, SG and SL are not statistically significant, with the lowest total protein concentration was measured in the SS group. Concentrations of testosterone is highest in the SG group, followed by LG and SL groups, between which there is no significant difference, and the lowest value was measured in the SS group, where the difference was statistically significant only in relation to the $\mathrm{SG}$ group $(\mathrm{p}<0.05)$.

\section{Discussion}

Extrusion significantly improves the performance, size of digestive organs and especially positive effect on the relative weight of the pancreas and digestion of food (Arija et al., 2006.; Brenes et al., 2008). These beneficial effects may be associated with reduction or inactivation of lectins, trypsin, and $\alpha$ himotripsin amylase inhibitor (Arija et al., 2006; Brenes et al., 2008). Extrusion also leads to starch gelatinisation and reduces the activity of trypsin inhibitors, which improves 
the conditions for efficient digestion of proteins in the small intestine of pigs (O'Doherty and Keady, 2001) and chickens (Arija et al., 2006). Crude genetically enhanced soybeans (Soja Lana) was as expected had a much lower level of trypsin inhibitors in comparison with the standard raw soybeans, as Kunitz trypsin inhibitor antitrypsin, main component of the seed (Friedman et al., 1991). Soybean varieties with low levels of Kunitz inhibitors may have different levels of trypsin inhibitors, depending on the spot they are grown (Kumar et al., 2003), the presence of other types of trypsin inhibitors (Tan-Wilson et al., 1987), variations in the level lipoksigegenase (Machado et al., 2008) and anti-nutritive factors such as phytates and tannins (Liener, 1994). Palacios et al. (2004) have obtained results by genetically improved strains that had better quality than standard soy protein, but Machado et al. (2008), in its biological assay did not perceive significant differences when the two varieties of soybean were thermally treated in the same way. This can be explained by different levels of lectins in different cultivars of soybean (Friedman et al., 1991). Differences in the quality of protein are expected due to variations in the quantity of different types of trypsin inhibitors and other anti-nutritive components in different varieties of soybean (Liener, 1994).

Cholesterol is the precursor of all steroid hormones and bile salts. Cholesterol levels may vary depending on the climatic conditions of the environment, nutrition, fitness broilers and sexual activity (Itoh et al., 1998). Cholesterol in plasma was reduced in the experiment Carew et al. (1998b) in chickens that are eaten raw or heat-treated grain legumes Mucuna prurens. Iauk et al. (1989) showed that feeding rats with legumes leading to lower cholesterol levels. Lowered plasma cholesterol in chickens that eat raw grain legumes indicates disruption of endogenous cholesterol metabolism, which is caused by ingestion of food (Arya, 2006). Similar results were obtained in our experiment when it comes to the SS group, but the unexpected result of the higher level of cholesterol in the SL group than in LG group, although the difference was not statistically significant. Protein, amino acid composition, lipid fractions, fiber and phytosterols legumes could affect the metabolic mechanisms that affect the intestinal microflora, and cholesterol synthesis and excretion of bile acids (Martins et al., 2004). The results of Martins et al. (2004) suggest the reduction of total cholesterol in plasma of piglets that were fed raw peas. Carew et al. (1998) argues that the effect of legumes on cholesterol in plasma is not associated with thermo sensitive factors in raw beans.

Triglyceride levels increased with age of female Japanese quail in the paper of Hassan (1998). Arija et al. (2006) have noted increased levels of triglycerides in groups that were fed extruded diets with a grain of beans. According to our results, triglyceride level was significantly higher in SG and LG groups fed extruded food in relation to the group which was fed raw soybeans, but unexpectedly high concentrations, even somewhat higher than in the SG group was 
observed in the group fed raw soybeans with reduced levels of trypsin from soybean inhibitor.

Oligosaccharides may have significant impact on reducing levels of cholesterol and triglycerides in rats fed with high fat content (Chen et al., 2010). Huang et al. (2006) showed that the activity of antioxidant enzymes in the liver, such as catalase, SOD and GPx were significantly increased when the soy oligosaccharides administered orally once a day to rats for 6 weeks. Chen et al. (2010) in in vivo studies have shown that soy oligosaccharides can be reduced, depending on the dose, lower oxidative stress and abnormal lipid levels in rats.

In the paper by Arija et al. (2006) increased concentration of grains in the mixture significantly decreases testosterone levels in broilers and this effect is attributed to the concentration of ANF in the raw grain. Besides this fact, no more information about the effects of ANF on steroid hormones in poultry. According to our results, the concentration is higher in the SS group, in which the concentration of trypsin inhibitors is higher than in the SL group, which is the level of trypsin inhibitors also decreased, while the extruded groups a higher level in the group who had higher levels of trypsin inhibitor prior to extrusion, and we can assume that if there is some anti nutritious factor that affects the testosterone, it is thermo sensitive and that was destroyed during the extrusion.

Soya bean contains isoflavonids (genistein and daidzein) that have estrogenic effects (Messina, 1999). Yousef et al. (2003) showed a positive effect of isoflavonids on biochemical parameters of blood in male rabbits. Isoflavonids led to the lowering of cholesterol and triglycerides. In our study, the concentration of testosterone was higher in groups fed extruded diets (SG and LG), The concentration is somewhat lower in the SL group, while the lowest in the SS group, with a statistically significant difference was observed only between the SG and SS groups. The results of Arija et al. (2006) point to a higher level of testosterone in groups fed legumes extruded grain. Also in the the same paper extrusion of grains has led to a significant increase of the concentration of cholesterol, triglycerides, and testosterone, while the total protein had no effect. According to our results, the highest level of total protein was in the SL group and was significantly higher than the SG and LG groups $(\mathrm{p}<0.05)$, and highly significant in relation to the SS group ( $\mathrm{p}<0.001)$. The lowest concentration was measured in the SS group. Feng et al. (2007) used a strain with a standard level of trypsin inhibitor and soybean, in which the level of trypsin inhibitors reduced fermentation from 2.6 to $0.0 \mathrm{mg} / \mathrm{g}$. Measured the total protein in serum of chicks aged 21 days and 42 days old chicks. Process of fermentation and lower levels of trypsin inhibitor had no significant effect on total protein, although slightly higher concentrations observed in the group fed fermented soy. Inactivation free trypsin in the intestine stimulates the release of cholecystokinin from neuroendocrine cells in the intestine, thus leading to hypersecretion of pancreatic digestive enzymes and the consequent increase in the pancreas (Lacourse et al., 1999). Cholecystokinin regulates growth of pancreatic enzyme secretion and its contraction of the gallbladder (Rehfeld, 1998), 
and thus the secretion of cholesterol in bile. Changes in gastrointestinal secretion affects the digestive structure and function, including a disturbance in the digestion and absorption, changes in the passage content, increased microbial activity in the small intestine and the entire increase in the digestive tract and associated organs (Hoerr, 1998). Size of the liver may be increased in response to several factors, especially in case of deficiency of protein and amino acids, which are associated with the presence of antinutritional factors in raw grains and legumes usually leads to accumulation of fat (Carew and Charles, 2003).

\title{
Conclusion
}

It is possible that the availability of protein and amino acids differ among the many varieties of soybean and other legumes, which can explain the different results obtained for the impact of legumes in the diet on biochemical parameters in serum.

Our experiment confirmed that in addition to Kunitz trypsin inhibitors are heat labile and other factors that influence different biochemical parameters of blood. Extrusion process destroys antinutritive factors and improves the nutritive value of soybeans and thus also act on the aforementioned parameters. Data on the effect of content Kunitz trypsin inhibitor in soya beans on serum biochemical parameters of broiler chickens is scarce. Limited observations require more research in this area. It also lacks information about the content of other antinutritional factors in soybean "Lana" and require further investigation of the varieties and possibilities of its application in animal nutrition.

\section{Acknowledgment}

Research was financed by the Ministry of Education and Science, Republic of Serbia, project TR 31033.

\section{Efekat antinutritivnih faktora i ekstrudiranja na nivo holesterola, triglicerida, ukupnih proteina i testosterona $u$ serumu brojlerskih pilića}

\author{
D. Beuković, D. Ljubojević, M. Beuković, D. Glamočić, S. Bjedov, V. Stanaćev
}

\section{Rezime}

Cilj rada je bio da se ispita efekat različitih antinutritivnih faktora i ekstrudiranja na nivo holesterola, triglicerida, ukupnih proteina i testosterona $u$ serumu brojlerskih pilića. Ogled je postavljen kao četiri tretmana sa po četiri 
ponavljanja, pri čemu su pilići hranjeni smešama sa različitim sortama soje i različitim načinom obrade iste. Grupe su bile: SS-sirova standardna soja, SL-sirova soja sa sniženim nivoom Kunitz tripsin inhibitora, SG-standardna ekstrudirana soja i LG-ekstrudirana soja sa sniženim nivoom tripsin inhibitora.

Značajno viši nivo holesterola u odnosu na SS grupu je i u SL grupi, a viši je i u LG grupi u odnosu na SS grupu, ali razlika nije značajna ( $>0,05)$. Između SL, SG i LG grupe nema statistički značajne razlike u nivou holesterola u serumu. Koncentracija triglicerida je najviša u LG grupi, zatim slede SL, pa SG grupa i između ove tri grupe nema statistički značajne razlike. Najniži nivo triglicerida je u SS grupi i on je statistički značajno niži u odnosu na ostale tri grupe. Nivo ukupnih proteina najviši je u SL grupi i značajno je viši u odnosu na SG i LG grupu $(p<0,05)$ i visoko značajna razlika je u odnosu na SS grupu. Razlike između grupa SS, SG i SL nisu statistički značajne, pri čemu je najniža koncentracija ukupnih proteina izmerena u SS grupi.

Oled je potvrdio da pored Kunitz tripsin inhibitora postoje i drugi termolabilni faktori koji različito utiču na biohemijske parametre krvi.

\section{References}

ANDERSON-HAFERMANN J. C., ZHANG Y., PARSONS C. M. (1992): Effect of heating on nutritional quality of conventional and Kunitz trypsin inhibitor-free soybeans. Poultry Science, 71, 1700-1709.

ARIJA I., CENTENO C., VIVEROS A., BRENES A., MARZO F., ILLERA J. C., SILVAN G. (2006): Nutritional Evaluation of Raw and Extruded Kidney Bean (Phaseolus vulgaris L.var. Pinto) in Chicken Diets. Poultry Science, 85, 635-644.

BIRK Y. (1961): Purification and some properties of a highly active inhibitor of trypsin and $\alpha$-chymotrypsin from soybeans. Biochim. Biophys. Acta, 54, 378-381.

BOWMAN D. E. (1944): Fractions derived from soy beans and navy beans which retard tryptic digestion of casein. Proc. Soc. Exp.Biol. Med, 57, 139-140.

BRENES A., VIVEROS A., CENTENO C., ARIJA I., MARZO F. (2008): Nutritional value of raw and extruded chickpeas (Cicer arietinum L.) for growing chickens. Spanish Journal of Agricultural Research, 6, 4, 537-545.

CAREW, L.B., ALSTER, F.A. and GERNAT, A.G. (1998): Blood chemistry including cholesterol, glucose andthyroid hormones of broilers fed raw velvet beans (Mucuna pruriens). Journal of Animal Science, 76, suppl. 2, 82.

CAREW L.B., HARDY D., WEIS J., ALSTER F., MISCHLER S.A., GERNAT, A., ZAKRZEWSKA E.I. (2003): Heating Raw Velvet Beans (Mucuna pruriens) Reverses some anti-nutritional effects on organ growth, blood chemistry, and organ histology in growing chickens. Tropical and Subtropical Agroecosystems, 1, 267275.

CAREW L.B., GERNAT A.G. (2006): Use of velvet beans, Mucuna spp., as afeed ingredient for poultry: a review. World's Poultry Science Journal, 62,131-144. 
CHEN H., LI-JUN L., JIAN-JUN Z., BO X., RUI L. (2010): Effect of soybean oligosaccharides on blood lipid, glucose levels and antioxidant enzymes activity in high fat rats. Food Chemistry 119, 1633-1636.

DOUGLAS M.W., PARSONS C.M., HYMOWITZ T. (1999): Nutritional evaluation of lectin-free soybeans for poultry. Poultry Science, 78, 91-95.

DURMIC Z., PETHICK D.W., MULLAN B.P., SCHULZE H., ACIULLY J.M., HAMPSON D.J. (2000): Extrusion of wheat or sorghum and/or addition of exogenous enzymes to pig diets influences the large intestinal microbiota but does not prevent development of swine dysentery following experimental challenge.Journal of Applied Microbiology. 89, 4, 678-686.

EL-KHALIK A. E., JANSSENS G.P.J. (2010): Effect of extrusion processing on starch gelatinisation and performance in poultry. World's Poultry Science Journal. 66, 53-64.

FENG J., LIU X., XU Z.R., LIU Y.Y., LU Y.P. (2007): Effects of Aspergillus oryzae 3.042 fermente soybean meal on growth performance and plasma biochemical parameters in broilers Animal Feed Science and Technology, 134, 235-242.

FRIEDMAN M., BRANDON D.L., BATES A.H., HYMOWITZ T. : (1991) Comparison of a commercial soybean cultivar and an isoline lacking the Kunitz trypsin inhibitor: composition, nutritional value and effects of heating. Journal of Agricultural and Food Chemistry, 39, 327-335.

GERTLER A., BIRK Y., BONDI A. (1966): A comparative study of the nutritional and physiological significance of pure soybeantrypsin inhibitors and of ethanolextracted soybean meals in chicks and rats. The Journal of Nutrition, 358-370.

HASSAN H.A. (1998): Variations in egg performance and plasma constituents at different ages of females. Japanese quaile Egyptian Poultry Science, 30, II, 565-581.

HOERR F.J. (1998): Pathogenesis of Enteric Diseases. Poultry Science, 77, 11501155 .

HYMOWITZ T. (1986): Genetics and breeding of soybeans lacking the Kunitz trypsin inhibitor. In: FRIEDMAN M. (ed.), Pages in Nutritional and Toxicological Significance of Enzyme Inhibitors in Foods. Plenum Press, New York, NY, 291-298. HUANG R.L., ZHANG Z.H., CHEN P.G., MA K.W., YANG L., CHEN, H. (2006): Effect of soybean-oligosaccharides on antioxidation and the immunity of broliers. Journal of Agricultural University of HeBei, 29, 88-94.

IAUK L., GALETI E.M. FORESTIERI A.M., KIRJAVAINEN S., TROVATO A. (1989): Mucuna pruriens decoction lowers cholesterol and total lipid plasma levels in the rat. Phytotherapy Research, 3, 263-264.

ITOH N., MAKITA T., KOIWA M. (1998): Characteristics of blood chemical parameters in male and female quails. Journal of Veterinary Medical Science, 60, 1035-1037. 
KAKADE M.L., ARNOLD R.L., LIENER I.E., WAIBEL P.E. (1969): Unavailability of cysteine fromtrypsin inhibitors as a factor contributing to poor nutritive value of navy beans. Journal of Nutrition, 99, 34-42.

KUMAR V., RANI A., TINDWANI C., JAIN M. (2003): Lipoxygenase isozymes and trypsin inhibitor activities in soybean as influenced by growing location. Food Chemistry, 83, 1, 79 .

KUNITZ M. (1945): Crystallization of a trypsin inhibitor from soybean. Science, 101, 668-669.

LACOURSE K.A., SWANBERG L.J., GILLESPIE P.J., REHFELD J.F., SAUNDERS T.L., SAMUELSON L.C. (1999): Pancreatic function in CCKdeficient mice:adaptation to dietary protein does not require CCK. Am J Physiol Gastrointest Liver Physiol, 276, 1302-1309.

LIENER I.E. (1994): Implications of antinutritional components in soybean foods. Critical Reviews in Food. Science and Nutrition, 34, 1, 31-67.

LIN S., HSIEH F., HUFF H.E. (1997): Effects of lipids and processing conditions on degree of starch gelatinization of extruded dry pet food. Food Science and Technology-Lebensmittel-Wissenschaft \&Technologie, 30, 754-761.

MACHADO F.P.P., QUEIRÓZ J.H., OLIVEIRA M.G.A.,PIOVESAN N.D, PELUZIO M.C.G., COSTA N.M.B. MOREIRA M.A. (2008): Effects of heating on protein quality of soybean flour devoid of Kunitz inhibitor and lectin. Food Chemistry, 107, 649-655.

MARTINS J.M., RIOTTOT M., DE ABREU M.C., LANC M.J., VIEGASCRESPO A.M., ALMEIDA J.A., FREIRE J.B., BENTO O.P. (2004): Dietary raw peas (Pisum sativum L.) reduce plasma total and LDL cholesterol and hepatic esterified cholesterol in intact and ileorectal anastomosed pigs fed cholesterol-rich diets. The journal of nutrition, 134, 3305-3312.

MESSINA J.M. (1999): Legumes and soybeans overview of their nutritional profiles and health effects. The American Journal of Clinical Nutrition, 70, 3, 439s450s.

MOUGHAN P.J., RUTHERFURD S.M. (1996): A new method for determining digestible reactive lysine in foods. Journal of Agriculture and Food Chemistry, 44, 2202-2209.

O'DOHERTY J.V., KEADY U. (2001): The effect of expander processing and extrusion on the nutritive value of peas for pigs. Animal Science, 72, 43-53,.

PALACIOS M.F., EASTER R.A., SOLTWEDEL K.T., PARSONS C.M., DOUGLAS M.W., HYMOWITZ T., PETTIGREW J.E. (2004): Effect of soybean variety and processing on growth performance of young chicks and pigs. Journal of Animal Science, 82, 1108-1114.

PARSONS C.M., ZHANG Y., ARABA M. (2000):Nutritional evaluation of soybean meals varying in oligosaccharide content. Poultry Science, 79, 1127-1131. 
PUGALENTHI M., VADIVEL V., SIDDHURAJU P. (2005): Alternative food/feed perspectives of an underutilized legume mucuna pruriens var. utilis. A Review Plant Foods for Human Nutrition, 60, 201-218.

REFSTIE S., STOREBAKKEN T., ROEM A.J. (1998): Feed consumption and conversion in Atlantic salmon (Salmo salar) fed diets with fish meal, extracted soybean meal or soybean meal with reduced content of oligosaccharides, trypsin inhibitors, lectins and soya antigens. Aquaculture, 162, 301-312.

SADEGHI G.H., MOHAMMADI L., IBRAHIM S.A., GRUBER K.J. (2009): Use of bitter vetch (Vicia ervilia) as a feed ingredient for poultry. World's Poultry Science Journal, 65, 51-64.

SIDDHURAJU P, BECKER K, MAKKER HS (2000): Studies on the nutritional composition and antinutritional factors of three different germplasm seed materials of an under-utilized tropical legume, Mucuna pruriens var. utilis. Journal of Agriculture Food Chemistry, 48, 6048-6060.

TAN-WILSON A.L., CHEN J.C., DUGGAN M.C., CHAPMAN C., OBACH R. S.,WILSON K.A. (1987): Soybean bowman-birk trypsin isoinhibitors: Classification and report of a glycine-rich trypsin inhibitor class. Journal of Agricultural and Food Chemistry, 35, 6, 974-981.

TULEUN C.D., IGBA F. (2008): Growth and carcass characteristics of broiler chickens fed water soaked and cooked velvet bean (Mucuna utilis) meal. African Journal of Biotechnology, 7, 15, 2676-2681.

YEN J.T., JENSEN A.H., SIMON J. (1977): Effect of dietary raw soybean and soybean trypsin inhibitor on trypsin and chymotrypsin activities in the pancreas and in small intestinal juice of growing swine. Journal of Nutrition, 107, 156-165. YOUSEF M.I., El-DEMERDASHA F.M., KAMELB K.I., Al-SALHENA K.S. (2003): Changes in some hematological and biochemical indices of rabbits induced by isoflavones and cypermethrin. Toxicology, 189, 3, 223-234

Received 30 June 2011; accepted for publication 15 August 2011 